\title{
Serologic and immunohistochemical prognostic biomarkers of cutaneous malignancies
}

\author{
Jochen Utikal • Dirk Schadendorf • Selma Ugurel
}

Received: 3 November 2006 / Revised: 6 December 2006 / Accepted: 6 December 2006 / Published online: 13 January 2007

(C) Springer-Verlag 2006

\begin{abstract}
Biomarkers are important tools in clinical diagnosis and prognostic classification of various cutaneous malignancies. Besides clinical and histopathological aspects (e.g. anatomic site and type of the primary tumour, tumour size and invasion depth, ulceration, vascular invasion), an increasing variety of molecular markers have been identified, providing the possibility of a more detailed diagnostic and prognostic subgrouping of tumour entities, up to even changing existing classification systems. Recently published gene expression or proteomic profiling data relate to new marker molecules involved in skin cancer pathogenesis, which may, after validation by suitable studies, represent future prognostic or predictive biomarkers in cutaneous malignancies. We, here, give an overview on currently known serologic and newer immunohistochemical biomarker molecules in the most common cutaneous malignancies, malignant melanoma, squamous cell carcinoma and cutaneous lymphoma, particularly emphasizing their prognostic and predictive significance.
\end{abstract}

J. Utikal · D. Schadendorf · S. Ugurel

Department of Dermatology,

Venereology and Allergology,

University Medical Center Mannheim,

Ruprecht-Karl-University of Heidelberg,

Theodor-Kutzer-Ufer 1-3, 68135 Mannheim, Germany

D. Schadendorf $\cdot$ S. Ugurel $(\square)$

Skin Cancer Unit,

German Cancer Research Center,

Heidelberg, Germany

e-mail: s.ugurel@dkfz.de
Keywords Skin cancer - Biomarker · Prognosis · Serum $\cdot$ Immunohistochemistry

\section{Introduction}

Biomarkers play an important role in the diagnosis and prognostic classification of various cancer entities and can moreover be useful in monitoring the patient's clinical course of disease and response to therapy. In general, biomarkers are proteins, less often carbohydrates or lipids, and their expression profiles are associated with malignant disease. In the majority of cases, the marker molecules are expressed by the tumour cells themselves or by cells of the tumour microenvironment. Thus, most biomarkers can primarily be found in malignant tissues, but after active secretion or passive release at tumour cell destruction also become detectable in body fluids like blood, lymph or urine.

Besides morphological and histopathological biomarkers (anatomic site and type of the primary tumour, tumour size and invasion depth, ulceration, vascular invasion), an increasing variety of molecular markers have been identified, providing the possibility of a more detailed diagnostic and prognostic subgrouping of tumour entities, up to even changing existing classification systems. Recently published gene expression, as well as proteomic profiling data, indicates new candidate molecules involved in skin cancer pathogenesis, which may after further validation represent new markers superior to existing ones. This ongoing process of biomarker identification and validation would result in a rapidly changing molecular view and classification of skin cancers. 


\section{Malignant melanoma}

Serologic markers of malignant melanoma

Despite numerous therapeutic options, the prognosis of malignant melanoma, once metastasized, is still poor. Thus, the search for reliable methods to detect metastases as early as possible and to identify patients with high risk of disease progression is of major importance. The serological parameters most widely used for the early detection of a tumour relapse or metastasis in the follow-up of melanoma patients are the melanocyte lineage/differentiation antigens S100-beta and melanoma inhibitory activity (MIA) (see Table 1 and Fig. 1). Both proteins are with high, but not exclusive, specificity expressed by melanoma cells and thus correlate with the patient's tumour load.

The S100 protein is a $21-\mathrm{kDa}$ thermo-labile acidic dimeric protein, which was originally isolated from the central nervous system (CNS) [49]. It consists of two subunits, alpha and beta, in the combinations alpha/ alpha, alpha/beta and beta/beta. S100 affects the assembly and disassembly of microtubules and also interacts in a calcium-dependent manner with the p53 tumour suppressor gene. The beta subunit is expressed in cells of the central nervous system as well as in cells of the melanocytic lineage. Therefore, S100-beta measured in the cerebrospinal fluid was known as a marker of CNS

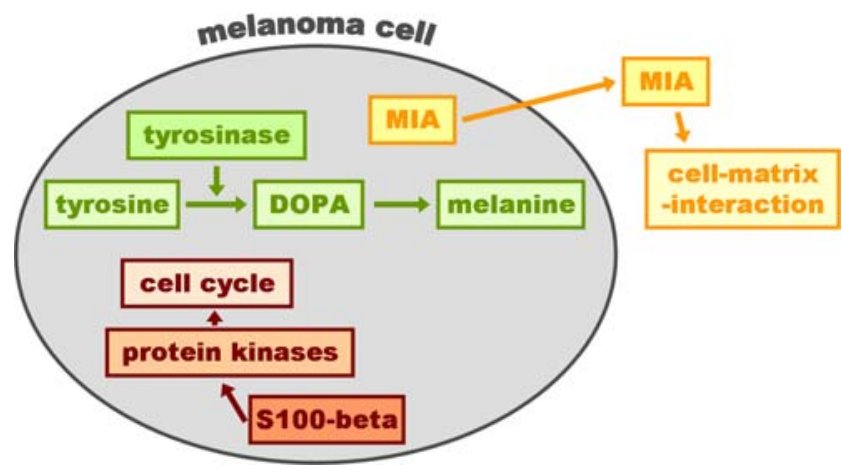

Fig. 1 Schematic presentation of the cellular localization and function of the melanoma biomarkers S100-beta, tyrosinase and melanoma inhibitory activity $(M I A)$

damage [59], years before S100-beta was shown to be a useful serum marker in melanoma [30]. MIA was originally detected in melanoma cell culture supernatant [9] and was shown to exert an important role in cellmatrix interaction and metastasis [8].

Serum S100-beta has been shown to be superior compared to MIA, as an early indicator of tumour progression, relapse or metastasis [18, 43], and its distribution as a serum biomarker of melanoma, therefore, is the broadest [36]. Both markers have been shown to be useful prognostic markers in melanoma patients with distant metastases (stage IV, classification system of the American Joint Committee on Cancer, AJCC, see

Table 1 Serologic markers of malignant melanoma

\begin{tabular}{|c|c|c|}
\hline & Serologic marker & Selected literature \\
\hline \multirow{5}{*}{$\begin{array}{l}\text { Melanocyte lineage/differentiation } \\
\text { antigens }\end{array}$} & S100-beta & {$[30,71,32,33,18,43,28]$} \\
\hline & MIA (melanoma inhibitory activity) & {$[9,8,10,74,28]$} \\
\hline & Tyrosinase & {$[2]$} \\
\hline & 5-S-Cysteinyldopa & {$[91,34]$} \\
\hline & L-Dopa/L-tyrosine & {$[75]$} \\
\hline \multirow[t]{3}{*}{ Proangiogenic factors } & VEGF (vascular endothelial growth factor) & {$[83,56,12]$} \\
\hline & BFGF (basic fibroblast growth factor) & {$[83,12]$} \\
\hline & IL-8 (Interleukin-8) & {$[68,83,12]$} \\
\hline \multirow{3}{*}{$\begin{array}{l}\text { Molecules involved in cell adhesion } \\
\text { and motility }\end{array}$} & sICAM-1 (soluble intracellular adhesion molecule 1) & {$[34,87,94]$} \\
\hline & sVCAM (soluble vascular cell adhesion molecule 1) & {$[26,87]$} \\
\hline & Matrix metalloproteinases (MMP)-1 and 9 & {$[63,53]$} \\
\hline \multirow[t]{3}{*}{ Cytokines and cytokine receptors } & IL-6 (Interleukin-6) & {$[50,73]$} \\
\hline & IL-10 (Interleukin-10) & {$[21,51]$} \\
\hline & sIL-2R (soluble interleukin-2-receptor) & {$[11,58]$} \\
\hline \multirow{2}{*}{ HLA molecules } & sHLA-DR (soluble HLA-DR) & {$[62]$} \\
\hline & sHLA-class-I (soluble HLA-class I) & [89] \\
\hline \multirow[t]{8}{*}{ Others } & LDH (lactate dehydrogenase) & {$[72,18,6]$} \\
\hline & CRP (C-reactive protein) & [19] \\
\hline & Albumin & [72] \\
\hline & TuM2-PK (Tumour pyruvate kinase type M2) & [81] \\
\hline & sFas/CD95 & {$[84]$} \\
\hline & YKL-40 & {$[69,70]$} \\
\hline & CYT-MAA (cytoplasmic melanoma-associated antigen) & {$[85]$} \\
\hline & $\begin{array}{l}\text { HMW-MAA (high-molecular-weight } \\
\text { melanoma-associated antigen) }\end{array}$ & {$[85]$} \\
\hline
\end{tabular}




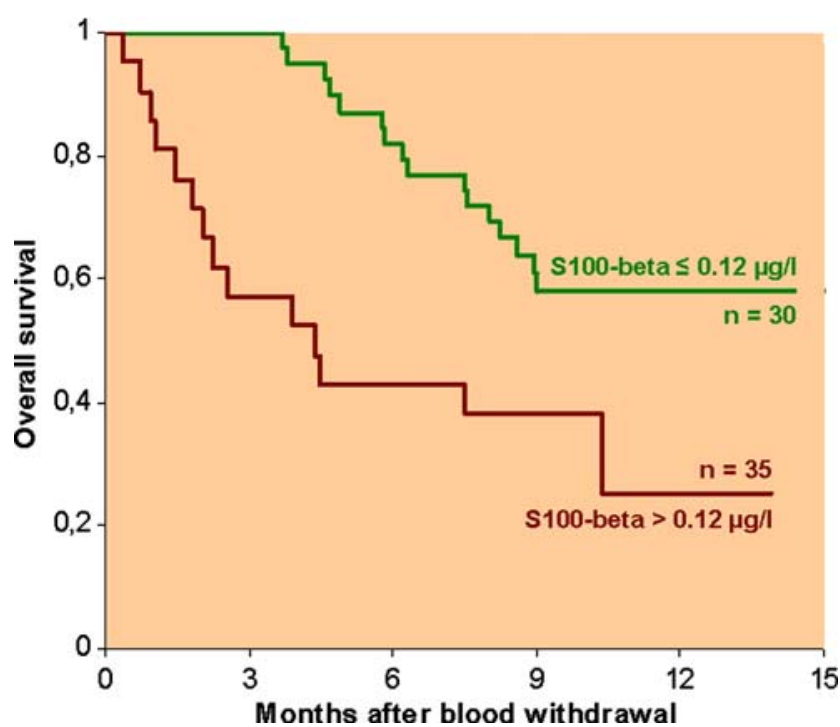

Fig. 2 Kaplan-Meier survival curves of 65 patients with advanced metastatic melanoma (AJCC stage IV). Patients with elevated serum levels of S100-beta show a significantly reduced survival probability compared to patients with normal S100-beta serum concentrations ( $P=0.003$ by log rank test; detection system LIAISON Sangtec 100)

Fig. 2) [71, 33], but fail to provide prognostic significance in early stages of melanoma, especially in patients who are tumour-free after surgical procedures [74]. Because of the strong correlation of their serum concentrations with the patients' tumour load, S100beta and MIA are useful markers in the monitoring of therapy response in advanced metastatic melanoma patients (AJCC stage IV) [32]. Again, none of both markers are suitable indicators of therapy response in tumour-free early-stage melanoma patients (AJCC stage II or III). Moreover, S100-beta has been shown to fail to identify patients with lymph node micrometastases detected by sentinel node procedure [1].

The strongest prognostic serum biomarker in advanced metastatic melanoma is lactate dehydrogenase (LDH), an unspecific marker indicating high tumour load in a variety of tumour entities, including melanoma. Studies comparing LDH, S100-beta and MIA using multivariate data analysis showed LDH to be the strongest independent prognostic factor in stage IV melanoma patients [18]. Due to its high prognostic significance, coupled with its easy, cost-efficient and widely distributed detection methodology, serum LDH is the only molecular marker that has been included in the current melanoma staging and classification system of the AJCC [6]. It, moreover, serves as a stratification parameter in most randomized therapy trials performed in stage-IV melanoma and may also be used to monitor therapy response in these patients.
A variety of other molecules of peripheral blood have been described as markers of tumour load and disease progression in melanoma. These biomarkers are derived from different fields like melanocytic differentiation (e.g. tyrosinase; see Fig. 1), tumour angiogenesis (e.g. VEGF, bFGF, IL-8), cell adhesion and motility (e.g. ICAM-1, MMPs), cytokines and their receptors (e.g. IL-6, IL-10), antigen presentation (e.g. HLA molecules), tumour cell metabolism (e.g. TuM2PK), apoptosis (e.g. Fas/CD95) and many others (see Table 1). However, neither one of these markers could be confirmed to be superior to S100-beta or LDH in reflecting the prognosis of patients in advanced disease stages, nor could any marker be shown to be of strong prognostic relevance in early stage tumour-free patients.

The serum proteomic profiling is an innovative approach to identify new, potentially better serological biomarkers in melanoma. This methodology offers the possibility of screening the whole serum proteome for markers, which match different criteria like prognostic significance, prediction of therapy response, etc. Using this technology, marker proteins from thematic fields, different from the above-mentioned ones, might be found and thereafter validated for their clinical use. The first promising results have been obtained and are currently tested in large sets of serum samples [46].

Immunohistochemical markers of malignant melanoma

Cutaneous malignant melanoma regularly develops from the radial to the vertical growth phase and thereafter to metastatic disease. The variability of this clinical course is only partially explained by morphological and histopathological parameters like primary tumour localization, patient gender and age, mitotic rate, tumour thickness and ulceration. There is a need to identify molecular variables, which help to assign patients to specific risk groups. The number of modalities for diagnosing and subclassifying malignant melanomas is rapidly increasing and includes immunohistochemistry of tissue sections and microarrays, gene expression profiling, comparative genomic hybridization and mutational analysis. These methodologies promise to improve our prognostic classification systems, as well as our diagnostic and therapeutic potential.

For diagnostic purposes, a small panel of melanocytic lineage markers, e.g. S100, MART-1/MelanA and gp100/HMB45, is sufficient to distinguish melanoma from non-melanocytic cancers. For the differentiation between benign and malignant melanocytic lesions, a 
review of immunohistochemical markers is given in ref. [44]. The present review focuses on newer markers with potential prognostic impact for the disease. For this purpose, the situation is more complex. The transformation from benign melanocytes to metastatic melanoma is the result of a compilation of genetic alterations crucial to cell division, differentiation, anti-apoptosis, invasion, angiogenesis and sustenance in a microenvironment distant from the point of origin of the cell. Several marker molecules involved in these genetic alterations have been identified, and their expression in primary melanoma has been studied and correlated with the prognosis. Table 2 gives a current overview on already identified biomarkers, whose abnormal expression is associated with the patient's prognosis. It may be expected that the most detailed prognostic classification will result not from one, but rather from a panel of multiple biomarkers from this list.

In a recent retrospective study, frozen tissue samples from primary melanomas with long-term clinical

Table 2 Immunohistochemical markers of malignant melanoma associated with prognosis

Association with poor prognosis

Increased expression

gp100/HMB45

Tumour suppressors/oncogenes/signal transducers p16 INK4A

PTEN

$\mathrm{pRb}$ (retinoblastoma protein)

EGFR (epidermal growth factor receptor)

p-Akt (activated serine-threonine protein kinase B)

c-Kit

c-myc

AP-2 (activator protein-2alpha) transcription factor

HDM2 (human homologue of murine mdm2)

bcl-6

Cell cycle associated proteins

Ki67 (detected by Mib1)

Cyclin A, B, D, E

p21 ${ }^{\mathrm{CIP} 1}$

Geminin

PCNA (proliferating cell nuclear antigen)

Regulators of apoptosis

bcl-2

bax

Bak

APAF-1 (Apoptotic protease activating factor-1)

Surviving

Molecules involved in angiogenesis

LYVE-1 (lymphatic vascular endothelial

hyaluronan receptor-1)

PTN (pleiotrophin)

Molecules involved in cell adhesion and motility

P-Cadherin

E-Cadherin

Beta-catenin

Integrins beta 1 and beta 3

MMPs (matrix metalloproteinases)

Dysadherin

CEACAM1 (carcinoembryonic-antigen-related cell-adhesion molecule 1 )

Osteonectin (also termed BM40 or SPARC

(secreted protein, acidic and rich in cysteine))

Others

TA (telomerase activity)

Melastatin

ALCAM/CD166

(Activated leukocyte cell adhesion molecule)

CXCR4 receptor

Metallothionein

Decreased expression

$\begin{array}{ll}\text { Decreased expression } & {[47,3]} \\ \text { Decreased expression } & {[48]} \\ \text { Inactivation due to protein } & {[65]} \\ \text { phosphorylation } & \\ \text { Increased expression } & {[80]} \\ \text { Increased expression } & {[17]} \\ \text { Expression } & {[35,82]} \\ \text { Increased expression } & {[42]} \\ \text { Loss of nuclear AP-2 expression } & {[7]} \\ \text { Increased expression } & {[61]} \\ \text { Expression } & {[3]}\end{array}$

Increased expression

Increased expression

Decreased expression

Increased expression

Increased expression

Increased expression

Decreased expression

Decreased expression

Increased expression

Increased expression

Increased expression

Strong cytoplasmic expression

Decreased expression

Loss of nuclear staining

Increased expression

Increased expression

Increased expression

Increased expression

Increased expression

Increased expression

Decreased expression

Increased expression

Increased expression

Increased expression
[29, 3, 57]

$[24,25]$

[3]

[92]

[92]

[78]

[23]

[23]

[27]

[78]

[16]

[93]

[5]

elected literature

2]

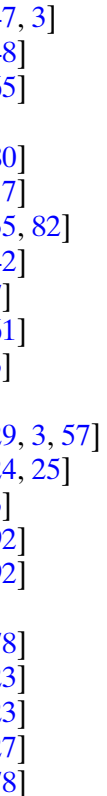


follow-up were analysed using a pangenomic oligonucleotide microarray [92]. The authors describe a signature of 174 genes, identifying patients at risk to develop distant metastasis. From these 174 genes, 141 were under-expressed and 33 were over-expressed in primary melanomas of patients who remained free of metastasis for 4 years. About 30 of these 174 genes have already been studied in melanoma and include genes involved in cell cycle (CKS2, CDC2, CCNB1, CENPF and DHFR), mitosis (HCAP-G and STK6), mitotic spindle checkpoint (BUB1), inhibition (BIRC5) or stimulation (GPR105) of apoptosis, DNA replication (TOP2A, RRM2, TYMS, PCNA, MCM4 and MCM6), stress response (GLRX2, DNAJA1, HSPA4, HSPA5, HSPD1 and TXNIP), ubiquitin cycle (SIP), actin and calmodulin binding (CNN3), intracellular signalling (STMN2), negative regulation of the Wnt signaling pathway (CTNNBIP1), inhibition of MITF expression (EMX2), regulation of proteolysis (TNA), testis cancer (CML66) and metastasis suppression (NME1). Winnepenninckx et al. [92] recommend the use of a battery of antibodies that may improve the future determination of prognosis and treatment stratification. The determination of karyopherin-alpha2, MCMs (minichromosome maintenance proteins), geminin and PCNA over-expression could be used for screening in melanoma patients with a poor clinical outcome.

\section{Squamous cell carcinoma of the skin}

While primary cutaneous squamous cell carcinomas (SCC) are usually easily treatable, they have the potential to recur locally and even metastasize, then leading to a significant morbidity and mortality. Therefore, it is important to identify those tumours that are more aggressive and require closer follow-up and additional treatments, such as lymph adenectomy or radiation therapy. Established prognostic factors include anatomic site of primary, tumour size, depth of invasion, rapid growth, grade of differentiation, perineural invasion, history of previous treatment, host immunosuppression, and etiologic factors such as burn scars, radiation and chronic ulceration. The histological subtypes of SCC have also been considered as a factor in determining the prognosis [60].

Only few molecular markers are known to be associated with progression or prognosis of cutaneous SCC. In the following, we give an overview on some recently described proteins whose abnormal expression contributes to a malignant phenotype in this cancer entity. STAT3, a member of the signal transducer and activator of transcription (STAT) family of transcription factors is a known regulator of cell motility. The expression of phosphorylated STAT3 (p-STAT3) was described to be stronger in poorly differentiated than in well-differentiated SCCs. Moreover, the percentage of tumour cells expressing p-STAT3 correlated with the depth of tumour invasion and with metastasis formation [76].

E-Cadherin is a $\mathrm{Ca}(2+)$-dependent, intercellular adhesion molecule that is specifically expressed in epithelial cells and tissues and functions by maintaining intercellular connections. In some types of carcinomas, E-cadherin expression of tumour cells is decreased in association with metastasis. In cutaneous SCC, a decreased expression of E-cadherin in the primary lesion is correlated with the development of regional lymph node metastasis [41]. Additionally, a decreased expression is more often associated with well-differentiated than with poorly differentiated SCC. Therefore, E-cadherin might be useful as a marker for the metastatic potential of well-differentiated SCC [41]. The simultaneous detection of p-STAT3 and E-cadherin may contribute to the prediction of prognosis of cutaneous SCC patients [76].

Another marker to distinguish between well-differentiated and poorly differentiated SCC is Ets-1 [37]. Ets-1 is a transcription factor regulating the expression of various genes including matrix metalloproteinases (MMPs). Therefore, Ets-1 might be important in the pathogenesis of invasive SCC. MMP-12 was found to be expressed by tumour cells in squamous cell carcinoma of the vulva. Its expression correlates with invasiveness, while that of macrophages predict a better clinical outcome [38]. A cell surface marker, CD44, is a glycoprotein widely distributed in the extracellular matrix. CD44 isoforms, which arise from alternative mRNA splicing, were found to be implicated in the formation of tumour metastasis. In a study by RodriguezRodriguez et al., it was shown that lymph node metastases of cutaneous SCC of the vulva were immunoreactive for CD44-9v [64]. Also, CD44-10v expression was present in $78 \%$ of tumours compared to only $56 \%$ of normal epithelium. CD44-10v membrane expression, but not cytoplasmic expression, correlates with disease recurrence [64]. In ocular squamous cell carcinomas, over-expression of CD44-6v is correlated with tumour progression and metastasis [55].

\section{Cutaneous T-cell lymphomas}

Cutaneous T-cell lymphomas (CTCL) are a heterogeneous group of cutaneous non-Hodgkin's lymphomas. 
In this cutaneous malignancy, the tumour cells home to and persist in the skin, producing a broad spectrum of clinical entities. The prognosis of CTCL depends on histologic and molecular aspects. The new WHO/ EORTC classification for cutaneous lymphomas comprises mature T-cell and natural killer (NK)-cell lymphomas, mature B-cell lymphomas and immature haematopoietic malignancies. Marker proteins for the diagnosis of CTCL include, for example, CD2, CD3, CD4, CD5, CD7, CD8, CD14, CD16/56, CD19, CD25, CD45, CD45RA and CD45R0 [90].

The probability of survival in CTCL can be accurately predicted by a formula based on the clinical CTCL-Severity-Index (CTCL-SI) [20], which evaluates the involvement of the skin, lymph nodes, blood and visceral organs [40]. Besides clinical and morphological parameters, several molecules have been investigated in CTCL that are involved in general cellular signalling processes, regulation of cellular proliferation and apoptosis, like Jun, Myc, c-myb, p53, STATs, bcl-2, Fas/CD95 and SOCS-3, or contribute to the putative immunopathology of the disease such as expression of inhibitory MHC receptors (ILT2/CD85j), NK receptors (p140/KIR3DL2) and dendritic cell defects (CD40). The abnormal expression of these molecules could be relevant for the prognosis of CTCL, as it has been shown for other tumour entities [39].

With regard to serological biomarkers in CTCL, it has been shown that the serum concentrations of the soluble alpha-chain of the interleukin-2 receptor (sIL$2 \mathrm{R})$ as well as lactate dehydrogenase (LDH) strongly correlate with lymph node size, but only sIL-2R significantly correlates with the severity of skin manifestations in erythrodermic patients [86]. Moreover, sIL-2R was demonstrated to be produced at a relatively low rate by tissue-based lymphoma cells, whereas large-cell transformation in CTCL results in a marked increase in the sIL-2R production in some patients [86]. In addition to sIL-2R, neopterin and beta2-microglobulin have been shown to be significantly elevated in the serum from patients with Sezary syndrome. Thus, sIL$2 \mathrm{R}$ seems to be the most sensitive marker, which is typically increased in Sezary syndrome. Concerning the outcome of the disease, in terms of disease progression versus non-progression, only neopterin showed a significant prognostic value in non-leukemic CTCL patients [31].

\section{Conclusion and future directions}

Taken together, molecular markers provide additional and much more detailed information for the prognostic classification of cutaneous malignancies. Currently, this is particularly true for malignant melanoma, but will certainly also affect other entities in due time. In addition to the serological and immunhistochemical biomarkers discussed here, genetic abnormalities have recently been recognized to influence the prognosis of cancer patients in higher extents than previously assumed. With regard to malignant melanoma, a new classification system was proposed combining genetic aberrations with histomorphological changes, resulting in new insights into the pathogenesis of this malignancy $[14,15]$. It may be expected that the rapidly increasing knowledge of molecular mechanisms would lead to mainly biomarker-based, rather than morphology-based, classification systems that might facilitate an individualized, molecular-driven cancer therapy.

Acknowledgments This work was supported by a grant from the German Cancer Aid/Deutsche Krebshilfe (Proposal No. 106856).

\section{References}

1. Acland K, Evans AV, Abraha H, Healy CM, Roblin P, Calonje E, Orchard G, Higgins E, Sherwood R, Russell-Jones R (2002) Serum S100 concentrations are not useful in predicting micrometastatic disease in cutaneous malignant melanoma. Br J Dermatol 146:832-835

2. Agrup P, Carstam R, Wittbjer A, Rorsman H, Rosengren E (1989) Tyrosinase activity in serum from patients with malignant melanoma. Acta Derm Venereol 69:120-124

3. Alonso SR, Ortiz P, Pollan M, Perez-Gomez B, Sanchez L, Acuna MJ, Pajares R, Martinez-Tello FJ, Hortelano CM, Piris MA, et al (2004) Progression in cutaneous malignant melanoma is associated with distinct expression profiles: a tissue microarray-based study. Am J Pathol 164:193-203

4. Andersen K, Nesland JM, Holm R, Florenes VA, Fodstad O, Maelandsmo GM (2004) Expression of S100A4 combined with reduced E-cadherin expression predicts patient outcome in malignant melanoma. Mod Pathol 17:990-997

5. Bachmann IM, Straume O, Puntervoll HE, Kalvenes MB, Akslen LA (2005) Importance of P-cadherin, beta-catenin, and Wnt5a/frizzled for progression of melanocytic tumors and prognosis in cutaneous melanoma. Clin Cancer Res 11:8606-8614

6. Balch CM, Buzaid AC, Soong SJ, Atkins MB, Cascinelli N, Coit DG, Fleming ID, Gershenwald JE, Houghton A Jr, Kirkwood JM, et al (2001) Final version of the American Joint Committee on Cancer staging system for cutaneous melanoma. J Clin Oncol 19:3635-3648

7. Berger AJ, Davis DW, Tellez C, Prieto VG, Gershenwald JE, Johnson MM, Rimm DL, Bar-Eli M (2005) Automated quantitative analysis of activator protein-2alpha subcellular expression in melanoma tissue microarrays correlates with survival prediction. Cancer Res 65:11185-11192

8. Blesch A, Bosserhoff AK, Apfel R, Behl C, Hessdoerfer B, Schmitt A, Jachimczak P, Lottspeich F, Buettner R, Bogdahn U (1994) Cloning of a novel malignant melanoma-derived growth-regulatory protein, MIA. Cancer Res 54:56955701 
9. Bogdahn U, Apfel R, Hahn M, Gerlach M, Behl C, Hoppe J, Martin R (1989) Autocrine tumor cell growth-inhibiting activities from human malignant melanoma. Cancer Res 49:5358-5363

10. Bosserhoff AK, Kaufmann M, Kaluza B, Bartke I, Zirngibl H, Hein R, Stolz W, Buettner R (1997) Melanoma-inhibitory activity, a novel serum marker for progression of malignant melanoma. Cancer Res 57:3149-3153

11. Boyano MD, Garcia-Vazquez MD, Lopez-Michelena T, Gardeazabal J, Bilbao J, Canavate ML, Galdeano AG, Izu R, Diaz-Ramon L, Raton JA, et al (2000) Soluble interleukin-2 receptor, intercellular adhesion molecule-1 and interleukin10 serum levels in patients with melanoma. $\mathrm{Br} \mathrm{J}$ Cancer 83:847-852

12. Brennecke S, Deichmann M, Naeher H, Kurzen H (2005) Decline in angiogenic factors, such as interleukin-8, indicates response to chemotherapy of metastatic melanoma. Melanoma Res 15:515-522

13. Carvalho L, Lipay M, Belfort F, Santos I, Andrade J, Haddad A, Brunstein F, Ferreira L (2006) Telomerase activity in prognostic histopathologic features of melanoma. J Plast Reconstr Aesthet Surg 59:961-968

14. Curtin JA, Busam K, Pinkel D, Bastian BC (2006) Somatic Activation of KIT in Distinct Subtypes of Melanoma. J Clin Oncol 14:14

15. Curtin JA, Fridlyand J, Kageshita T, Patel HN, Busam KJ, Kutzner H, Cho KH, Aiba S, Brocker EB, LeBoit PE, et al (2005) Distinct sets of genetic alterations in melanoma. N Engl J Med 353:2135-2147

16. Dadras SS, Paul T, Bertoncini J, Brown LF, Muzikansky A, Jackson DG, Ellwanger U, Garbe C, Mihm MC, Detmar M (2003) Tumor lymphangiogenesis: a novel prognostic indicator for cutaneous melanoma metastasis and survival. Am $\mathbf{J}$ Pathol 162:1951-1960

17. Dai DL, Martinka M, Li G (2005) Prognostic significance of activated Akt expression in melanoma: a clinicopathologic study of 292 cases. J Clin Oncol 23:1473-1482

18. Deichmann M, Brenner A, Bock M, Jäckel A, Uhl K, Waldmann V, Näher H (1999) S100-beta, melanoma-inhibiting activity and lactate dehydrogenase discriminate progressive from non-progressive American Joint Committee on Cancer stage IV melanoma. J Clin Oncol 17:1891-1896

19. Deichmann M, Kahle B, Moser K, Wacker J, Wust K (2004) Diagnosing melanoma patients entering American Joint Committee on Cancer stage IV, C-reactive protein in serum is superior to lactate dehydrogenase. Br J Cancer 91:699_ 702

20. Dippel E, Goerdt S, Assaf C, Stein H, Orfanos CE (1997) Cutaneous T-cell lymphoma severity index and T-cell gene rearrangement. Lancet 350:1776-1777

21. Dummer W, Becker JC, Schwaaf A, Leverkus M, Moll T, Brocker EB (1995) Elevated serum levels of interleukin-10 in patients with metastatic malignant melanoma. Melanoma Res 5:67-68

22. Duncan LM, Deeds J, Hunter J, Shao J, Holmgren LM, Woolf EA, Tepper RI, Shyjan AW (1998) Down-regulation of the novel gene melastatin correlates with potential for melanoma metastasis. Cancer Res 58:1515-1520

23. Fecker LF, Geilen CC, Tchernev G, Trefzer U, Assaf C, Kurbanov BM, Schwarz C, Daniel PT, Eberle J (2006) Loss of proapoptotic Bcl-2-related multidomain proteins in primary melanomas is associated with poor prognosis. $\mathrm{J}$ Invest Dermatol 126:1366-1371

24. Florenes VA, Faye RS, Maelandsmo GM, Nesland JM, Holm R (2000) Levels of cyclin D1 and D3 in malignant melanoma: deregulated cyclin D3 expression is associated with poor clinical outcome in superficial melanoma. Clin Cancer Res 6:3614-3620

25. Florenes VA, Maelandsmo GM, Faye R, Nesland JM, Holm R (2001) Cyclin a expression in superficial spreading malignant melanomas correlates with clinical outcome. J Pathol 195:530-536

26. Franzke A, Probst-Kepper M, Buer J, Duensing S, Hoffmann R, Wittke F, Volkenandt M, Ganser A, Atzpodien J (1998) Elevated pretreatment serum levels of soluble vascular cell adhesion molecule 1 and lactate dehydrogenase as predictors of survival in cutaneous metastatic malignant melanoma. Br J Cancer 78:40-45

27. Fujimoto A, Takeuchi H, Taback B, Hsueh EC, Elashoff D, Morton DL, Hoon DS (2004) Allelic imbalance of 12q22-23 associated with APAF-1 locus correlates with poor disease outcome in cutaneous melanoma. Cancer Res 64:2245-2250

28. Garbe C, Leiter U, Ellwanger U, Blaheta HJ, Meier F, Rassner G, Schittek B (2003) Diagnostic value and prognostic significance of protein S-100beta, melanoma-inhibitory activity, and tyrosinase/MART-1 reverse transcription-polymerase chain reaction in the follow-up of high-risk melanoma patients. Cancer 97:1737-1745

29. Gimotty PA, Van Belle P, Elder DE, Murry T, Montone KT, $\mathrm{Xu}$ X, Hotz S, Raines S, Ming ME, Wahl P, et al (2005) Biologic and prognostic significance of dermal Ki67 expression, mitoses, and tumorigenicity in thin invasive cutaneous melanoma. J Clin Oncol 23:8048-8056

30. Guo HB, Stoffel-Wagner B, Bierwirth T, Mezger J, Klingmuller D (1995) Clinical significance of serum S100 in metastatic malignant melanoma. Eur J Cancer 31A:924-928

31. Hassel JC, Meier R, Joller-Jemelka H, Burg G, Dummer R (2004) Serological immunomarkers in cutaneous T cell lymphoma. Dermatology 209:296-300

32. Hauschild A, Engel G, Brenner W, Glaeser R, Moenig H, Henze E, Christophers E (1999a) Predictive value of serum S100B for monitoring patients with metastatic melanoma during chemotherapy and/or immunotherapy. Br J Dermatol 140:1065-1071

33. Hauschild A, Engel G, Brenner W, Glaeser R, Monig H, Henze E, Christophers E (1999b) S100B protein detection in serum is a significant prognostic factor in metastatic melanoma. Oncology 56:338-344

34. Hirai S, Kageshita T, Kimura T, Tsujisaki M, Imai K, Wakamatsu K, Ito S, Ono T (1997) Serum levels of sICAM-1 and 5-S-cysteinyldopa as markers of melanoma progression. Melanoma Res 7:58-62

35. Janku F, Novotny J, Julis I, Julisova I, Pecen L, Tomancova V, Kocmanova G, Krasna L, Krajsova I, Stork J, et al (2005) KIT receptor is expressed in more than $50 \%$ of early-stage malignant melanoma: a retrospective study of 261 patients. Melanoma Res 15:251-256

36. Jury CS, McAllister EJ, MacKie RM (2000) Rising levels of serum S100 protein precede other evidence of disease progression in patients with malignant melanoma. Br J Dermatol 143:269-274

37. Keehn CA, Smoller BR, Morgan MB (2004) Ets-1 immunohistochemical expression in non-melanoma skin carcinoma. $\mathrm{J}$ Cutan Pathol 31:8-13

38. Kerkela E, Ala-aho R, Klemi P, Grenman S, Shapiro SD, Kahari VM, Saarialho-Kere U (2002) Metalloelastase (MMP12) expression by tumour cells in squamous cell carcinoma of the vulva correlates with invasiveness, while that by macrophages predicts better outcome. J Pathol 198:258-269

39. Klemke CD, Goerdt S, Schrama D, Becker JC (2006) New insights into the molecular biology and targeted therapy of cutaneous T-cell lymphomas. J Dtsch Dermatol Ges 4:395-406 
40. Klemke CD, Mansmann U, Poenitz N, Dippel E, Goerdt S (2005) Prognostic factors and prediction of prognosis by the CTCL Severity Index in mycosis fungoides and Sezary syndrome. Br J Dermatol 153:118-124

41. Koseki S, Aoki T, Ansai S, Hozumi Y, Mitsuhashi Y, Kondo S (1999) An immunohistochemical study of E-cadherin expression in human squamous cell carcinoma of the skin: relationship between decreased expression of E-cadherin in the primary lesion and regional lymph node metastasis. J Dermatol 26:416-422

42. Kraehn GM, Utikal J, Udart M, Greulich KM, Bezold G, Kaskel P, Leiter U, Peter RU (2001) Extra c-myc oncogene copies in high risk cutaneous malignant melanoma and melanoma metastases. Br J Cancer 84:72-79

43. Krähn G, Kaskel P, Sander S, Waizenhofer PJ, Wortmann S, Leiter U, Peter RU (2001) S100 beta is a more reliable tumor marker in peripheral blood for patients with newly occurred melanoma metastases compared with MIA, albumin and lactate-dehydrogenase. Anticancer Res 21:1311-1316

44. Mangini J, Li N, Bhawan J (2002) Immunohistochemical markers of melanocytic lesions: a review of their diagnostic usefulness. Am J Dermatopathol 24:270-281

45. Massi D, Franchi A, Borgognoni L, Reali UM, Santucci M (1999) Osteonectin expression correlates with clinical outcome in thin cutaneous malignant melanomas. Hum Pathol 30:339-344

46. Mian S, Ugurel S, Parkinson E, Schlenzka I, Dryden I, Lancashire L, Ball G, Creaser C, Rees R, Schadendorf D (2005) Serum fingerprinting discriminates between clinical stages and predicts disease progression in melanoma patients. J Clin Oncol 23:5088-5093

47. Mihic-Probst D, Mnich CD, Oberholzer PA, Seifert B, Sasse B, Moch H, Dummer R (2006) p16 expression in primary malignant melanoma is associated with prognosis and lymph node status. Int J Cancer 118:2262-2268

48. Mikhail M, Velazquez E, Shapiro R, Berman R, Pavlick A, Sorhaindo L, Spira J, Mir C, Panageas KS, Polsky D, et al (2005) PTEN expression in melanoma: relationship with patient survival, Bcl-2 expression, and proliferation. Clin Cancer Res 11:5153-5157

49. Moore BW (1965) A soluble protein characteristic of the nervous system. Biochem Biophys Res Commun 19:739-744

50. Mouawad R, Benhammouda A, Rixe O, Antoine EC, Borel C, Weil M, Khayat D, Soubrane C (1996) Endogenous interleukin 6 levels in patients with metastatic malignant melanoma: correlation with tumor burden. Clin Cancer Res 2:1405-1409

51. Nemunaitis J, Fong T, Shabe P, Martineau D, Ando D (2001) Comparison of serum interleukin-10 (IL-10) levels between normal volunteers and patients with advanced melanoma. Cancer Invest 19:239-247

52. Niezabitowski A, Czajecki K, Rys J, Kruczak A, Gruchala A, Wasilewska A, Lackowska B, Sokolowski A, Szklarski W (1999) Prognostic evaluation of cutaneous malignant melanoma: a clinicopathologic and immunohistochemical study. J Surg Oncol 70:150-160

53. Nikkola J, Vihinen P, Vuoristo MS, Kellokumpu-Lehtinen P, Kahari VM, Pyrhonen S (2005) High serum levels of matrix metalloproteinase-9 and matrix metalloproteinase-1 are associated with rapid progression in patients with metastatic melanoma. Clin Cancer Res 11:5158-5166

54. Nishizawa A, Nakanishi Y, Yoshimura K, Sasajima Y, Yamazaki N, Yamamoto A, Hanada K, Kanai Y, Hirohashi S (2005) Clinicopathologic significance of dysadherin expression in cutaneous malignant melanoma: immunohistochemical analysis of 115 patients. Cancer 103:1693-1700
55. Niu Y, Liu F, Zhou Z, Wang H (2002) Expression of CD44V6 and PCNA in squamous cell carcinomas. Chin Med J (Engl) 115:1564-1568

56. Osella-Abate S, Quaglino P, Savoia P, Leporati C, Comessatti A, Bernengo MG (2002) VEGF-165 serum levels and tyrosinase expression in melanoma patients: correlation with the clinical course. Melanoma Res 12:325-334

57. Ostmeier H, Fuchs B, Otto F, Mawick R, Lippold A, Krieg V, Suter L (2001) Prognostic immunohistochemical markers of primary human melanomas. Br J Dermatol 145:203-209

58. Ottaiano A, Leonardi E, Simeone E, Ascierto PA, Scala S, Calemma R, Bryce J, Caraco C, Satriano RA, Gianfranco N, et al (2006) Soluble interleukin-2 receptor in stage I-III melanoma. Cytokine 33:150-155

59. Persson L, Hardemark HG, Gustafsson J, Rundstrom G, Mendel-Hartvig I, Esscher T, Pahlman S (1987) S-100 protein and neuron-specific enolase in cerebrospinal fluid and serum: markers of cell damage in human central nervous system. Stroke 18:911-918

60. Petter G, Haustein UF (2000) Histologic subtyping and malignancy assessment of cutaneous squamous cell carcinoma. Dermatol Surg 26:521-530

61. Polsky D, Melzer K, Hazan C, Panageas KS, Busam K, Drobnjak M, Kamino H, Spira JG, Kopf AW, Houghton A, et al (2002) HDM2 protein overexpression and prognosis in primary malignant melanoma. J Natl Cancer Inst 94:1803-1806

62. Rebmann V, Ugurel S, Tilgen W, Reinhold U, Grosse-Wilde $\mathrm{H}$ (2002) Soluble HLA-DR is a potent predictive indicator of disease progression in serum from early-stage melanoma patients. Int J Cancer 100:580-585

63. Redondo P, Lloret P, Idoate M, Inoges S (2005) Expression and serum levels of MMP-2 and MMP-9 during human melanoma progression. Clin Exp Dermatol 30:541-545

64. Rodriguez-Rodriguez L, Sancho-Torres I, Gibbon DG, Watelet LF, Mesonero C (2000) CD44-9v and CD44-10v are potential molecular markers for squamous cell carcinoma of the vulva. J Soc Gynecol Investig 7:70-75

65. Roesch A, Becker B, Meyer S, Wild P, Hafner C, Landthaler M, Vogt T (2005) Retinoblastoma-binding protein 2-homo$\log$ 1: a retinoblastoma-binding protein downregulated in malignant melanomas. Mod Pathol 18:1249-1257

66. Saalbach A, Wetzel A, Haustein UF, Sticherling M, Simon JC, Anderegg U (2005) Interaction of human Thy-1 (CD 90) with the integrin alphavbeta3 (CD51/CD61): an important mechanism mediating melanoma cell adhesion to activated endothelium. Oncogene 24:4710-4720

67. Scala S, Ottaiano A, Ascierto PA, Cavalli M, Simeone E, Giuliano P, Napolitano M, Franco R, Botti G, Castello G (2005) Expression of CXCR4 predicts poor prognosis in patients with malignant melanoma. Clin Cancer Res 11:1835-1841

68. Scheibenbogen C, Mohler T, Haefele J, Hunstein W, Keilholz $\mathrm{U}$ (1995) Serum interleukin-8 (IL-8) is elevated in patients with metastatic melanoma and correlates with tumor load. Melanoma Res 5:179-181

69. Schmidt H, Johansen JS, Gehl J, Geertsen PF, Fode K, von der Maase H (2006a) Elevated serum level of YKL-40 is an independent prognostic factor for poor survival in patients with metastatic melanoma. Cancer 106:1130-1139

70. Schmidt H, Johansen JS, Sjoegren P, Christensen IJ, Sorensen BS, Fode K, Larsen J, von der Maase H (2006b) Serum YKL-40 predicts relapse-free and overall survival in patients with American Joint Committee on Cancer stage I and II melanoma. J Clin Oncol 24:798-804

71. Schultz ES, Diepgen TL, Von Den Driesch P (1998) Clinical and prognostic relevance of serum S-100 beta protein in malignant melanoma. Br J Dermatol 138:426-430 
72. Sirott MN, Bajorin DF, Wong GY, Tao Y, Chapman PB, Templeton MA, Houghton AN (1993) Prognostic factors in patients with metastatic malignant melanoma. A multivariate analysis. Cancer 72:3091-3098

73. Soubrane C, Rixe O, Meric JB, Khayat D, Mouawad R (2005) Pretreatment serum interleukin-6 concentration as a prognostic factor of overall survival in metastatic malignant melanoma patients treated with biochemotherapy: a retrospective study. Melanoma Res 15:199-204

74. Stahlecker J, Gauger A, Bosserhoff A, Buettner R, Ring J, Hein R (2000) MIA as a reliable tumor marker in the serum of patients with malignant melanoma. Anticancer Res 20:5041-5044

75. Stoitchkov K, Letellier S, Garnier JP, Bousquet B, Tsankov N, Morel P, Ghanem G, Le Bricon T (2003) Evaluation of the serum L-dopa/L-tyrosine ratio as a melanoma marker. Melanoma Res 13:587-593

76. Suiqing C, Min Z, Lirong C (2005) Overexpression of phosphorylated-STAT3 correlated with the invasion and metastasis of cutaneous squamous cell carcinoma. J Dermatol 32:354-360

77. Swart GW, Lunter PC, Kilsdonk JW, Kempen LC (2005) Activated leukocyte cell adhesion molecule (ALCAM/ CD166): signaling at the divide of melanoma cell clustering and cell migration? Cancer Metastasis Rev 24:223-236

78. Tas F, Duranyildiz D, Argon A, Oguz H, Camlica H, Yasasever V, Topuz E (2004) Serum bcl-2 and survivin levels in melanoma. Melanoma Res 14:543-546

79. Thies A, Moll I, Berger J, Wagener C, Brummer J, Schulze HJ, Brunner G, Schumacher U (2002) CEACAM1 expression in cutaneous malignant melanoma predicts the development of metastatic disease. J Clin Oncol 20:2530-2536

80. Udart M, Utikal J, Krahn GM, Peter RU (2001) Chromosome 7 aneusomy. A marker for metastatic melanoma? Expression of the epidermal growth factor receptor gene and chromosome 7 aneusomy in nevi, primary malignant melanomas and metastases. Neoplasia 3:245-254

81. Ugurel S, Bell N, Sucker A, Zimpfer A, Rittgen W, Schadendorf D (2005a) Tumor type M2 pyruvate kinase (TuM2-PK) as a novel plasma tumor marker in melanoma. Int $\mathrm{J}$ Cancer 117:825-830

82. Ugurel S, Hildenbrand R, Zimpfer A, La Rosee P, Paschka P, Sucker A, Keikavoussi P, Becker JC, Rittgen W, Hochhaus A, et al (2005b) Lack of clinical efficacy of imatinib in metastatic melanoma. Br J Cancer 92:1398-1405

83. Ugurel S, Rappl G, Tilgen W, Reinhold U (2001a) Increased serum concentration of angiogenic factors in malignant melanoma patients correlates with tumor progression and survival. J Clin Oncol 19:577-583

84. Ugurel S, Rappl G, Tilgen W, Reinhold U (2001b) Increased soluble CD95 (sFas/CD95) serum level correlates with poor prognosis in melanoma patients. Clin Cancer Res 7:12821286

85. Vergilis IJ, Szarek M, Ferrone S, Reynolds SR (2005) Presence and prognostic significance of melanoma-associated antigens CYT-MAA and HMW-MAA in serum of patients with melanoma. J Invest Dermatol 125:526-531

86. Vonderheid EC, Zhang Q, Lessin SR, Polansky M, Abrams JT, Bigler RD, Wasik MA (1998) Use of serum soluble interleukin-2 receptor levels to monitor the progression of cutaneous T-cell lymphoma. J Am Acad Dermatol 38:207-220

87. Vuoristo MS, Laine S, Huhtala H, Parvinen LM, Hahka-Kemppinen M, Korpela M, Kumpulainen E, Kellokumpu-Lehtinen P (2001) Serum adhesion molecules and interleukin-2 receptor as markers of tumour load and prognosis in advanced cutaneous melanoma. Eur J Cancer 37:1629-1634

88. Weinlich G, Eisendle K, Hassler E, Baltaci M, Fritsch PO, Zelger B (2006) Metallothionein-overexpression as a highly significant prognostic factor in melanoma: a prospective study on 1270 patients. Br J Cancer 94:835-841

89. Westhoff U, Fox C, Otto FJ (1998) Soluble HLA class I antigens in plasma of patients with malignant melanoma. Anticancer Res 18:3789-3792

90. Willemze R, Jaffe ES, Burg G, Cerroni L, Berti E, Swerdlow SH, Ralfkiaer E, Chimenti S, Diaz-Perez JL, Duncan LM, et al (2005) WHO-EORTC classification for cutaneous lymphomas. Blood 105:3768-3785

91. Wimmer I, Meyer JC, Seifert B, Dummer R, Flace A, Burg G (1997) Prognostic value of serum 5-S-cysteinyldopa for monitoring human metastatic melanoma during immunochemotherapy. Cancer Res 57:5073-5076

92. Winnepenninckx V, Lazar V, Michiels S, Dessen P, Stas M, Alonso SR, Avril MF, Ortiz Romero PL, Robert T, Balacescu O, et al (2006) Gene expression profiling of primary cutaneous melanoma and clinical outcome. J Natl Cancer Inst 98:472-482

93. Wu H, Barusevicius A, Babb J, Klein-Szanto A, Godwin A, Elenitsas R, Gelfand JM, Lessin S, Seykora JT (2005) Pleiotrophin expression correlates with melanocytic tumor progression and metastatic potential. J Cutan Pathol 32:125-130

94. Yamada M, Yanaba K, Takehara K, Sato S (2005) Clinical significance of serum levels of soluble intercellular adhesion molecule- 1 and soluble L-selectin in malignant melanoma. Arch Dermatol Res 297:256-260 